\title{
WALSH, KORT FORTALT
}

RICHARD WALSH: A CONTEXTUAL EXPOSITION OF BASIC TENETS | This essay is an attempt to reconstruct the logical structure of Walsh's argument in "The pragmatics of fictionality" (Chapter I of The Rhetoric of Fictionality). Its main focus is on the implications of Walsh's criticism of Fictional Worlds Theory and the issue of fictional reference, and on the relation between the rhetoric of fictionality and narratology.

KEYWORDS I Fiction, fictionality, rhetoric, narratology, pragmatics, relevance, implicature, speech acts, cognition, reference, communication

\section{Lidt om baggrunden}

For snart Ioo år siden forsøgte Percy Lubbock i The Craft of Fiction under inspiration fra Aristoteles og den oldgræske idé om 'mimesis' at bringe en vis orden i romankritikkens terminologi: "[F]iktionens kunst begynder først, når [forfatteren] tænker sin historie som noget, der skal vises, som skal fremstilles sådan, at den fortæller sig selv” (Lubbock 62). I I957 præsenterede Käte Hamburger i Logik der Dichtung et tilsvarende forsøg på at etablere relevansen af Aristoteles' poetik i litteraturteorien. Men mens Lubbocks bog blev relativt godt modtaget i den angelsaksiske verden, hvor den efterhånden blev skoledannende og brugt og misbrugt over en bred front (men den blev dog ikke oversat til fransk eller tysk), fandt Hamburgers Logik, skønt ofte nævnt og diskuteret af mange, ikke rigtigt fodfæste i litteraturteoretiske kredse. Den blev ganske vist med tiden oversat, til engelsk i 1973 og til fransk i 1986, men hendes fiktionsteori om fortællinger uden fortællere og et "episk præteritum", som placerer læseren i en deiktisk samtidighed med det fortalte, fik næppe den respons, den fortjente. 1972 udkom narratologiens initierende værk, Gérard Genettes Discours du récit (engelsk oversættelse Narrative Discourse 1980), som i modsætning til Lubbock og Hamburger i hele sin grundholdning er præget af en antimimetisk positur, som senere ser ud til at være blevet narratologiens dominerende kendetegn, af mange opfattet som dens adelsmærke. Det er derfor nok ikke i narratologiens hovedstrømninger, vi skal lede, hvis vi vil finde rester af Lubbocks insisteren på forskellen mellem telling og showing og forfattere, der leverer fortællinger, hvor historien "fortæller sig selv", eller Hamburgers insisteren på fortællinger uden fortællere etc., men snarere hos litteraturinteresserede teoretikere uden for det narratologiske felt, for eksempel filosoffer, lingvister og antropologer. I den 
pragmatiske sprogteori, begyndende med J.L. Austins Wittgenstein-inspirerede How to do Things with Words (1962), burde det være muligt at betragte det at bruge ord til at vise, hvad der foregår i og mellem mennesker, og så det at bruge ord til at rapportere det som to forskellige sproghandlinger.

En af de første, der griber denne mulighed, er Mary Louise Pratt. I Toward a Speech Act Theory of Literary Discourse (I977) argumenterer hun imod den tjekkiske formalismes og den amerikanske nykritiks modstilling af litterært og ordinært sprog, ifølge hvilken det litterære sprog er en egen sfære af æstetisk udsøgt og opfindsomt sprog, mens det ordinære sprog er nytteorienteret, kommunikativt, kommercialiseret, nedslidt, stereotypt og upoetisk, uden kreativ brug af figurer og troper. Klassisk narratologi arver åbenbart denne dikotomi, idet det ligger den fjernt at opfatte litterære fortællinger som kommunikationer. ("Hvis man kunne sige, hvad en roman kommunikerer, var der ingen grund til at skrive den (eller læse den)".) Pratt frakender den formalistiske dikotomi enhver værdi og viser, ved hjælp af William Labovs sociolingvistiske undersøgelser (1966, 1972), at også "naturlige” fortællinger bruger kunstgreb etc., som vi kender fra litterære fortællinger. Derfor må de samme sprogbrugsanalyser kunne anvendes på litterære værker, og litterære sætninger opfattes som talehandlinger (speech acts).

Et vigtigt spørgsmål i talehandlingsteorien handler om, hvilke betingelser der må antages at foreligge, for at en sproghandling kan siges at være hensigtsmæssig eller vellykket $i$ en given kommunikationssituation. Når de rigtige kontekstuelle betingelser er til stede, siges talehandlingen, alt andet lige, at være relevant. Således kan Pratt, måske som en af de første blandt talehandlingsteoretikerne, opstille et relevanskriterium for den talehandling at fortælle, nemlig at den skal være fortclbar (tellable):

"Påstande, hvis relevans er fortælbarhed, må repræsentere sagsforhold, der opfattes som usædvanlige, uventede eller på anden måde problematiske; informerende påstande kan gøre det, men de behøver det ikke, og det er ikke deres pointe at gøre det. Begge typer bruges til at informere, men de informerer af forskellige grunde. Ved at levere en påstand, hvis relevans er fortælbarhed, vil taleren ikke kun rapportere, men også verbalt vise et sagsforhold og invitere $\sin (\mathrm{e})$ adressat(er) til sammen med ham at tænke over det, evaluere det, og respondere på det.” (Pratt I36)

Således dukker litteraten Lubbocks nu diskrediterede modstilling af telling og showing op i en lingvistisk kontekst. Men netop denne kontekst forvandler begrebsparret fra en narratologisk til en helt særlig kommunikationsorienteret pointe. Citatets fortsættelse gør det helt klart, at hvis det her drejer sig om kommunikation, så handler det ikke først og fremmest om overbringelse af en informationsmængde, for pointen er en anden; den handler om at invitere og engagere andre til at tage del i noget - en oplevelse, en experience:

"[Talerens] pointe er at producere hos sine tilhørere, ikke kun tro, men også et fantasi- og affekt-engagement i det sagsforhold, han er ved at repræsentere, og en vurderende holdning til det. Hans intention er at få dem til at tage del i den 
forundring, glæde, rædsel eller beundring, som begivenheden har givet ham. I sidste ende er han måske ude efter en fortolkning af den problematiske begivenhed, en menings- eller værditilskrivelse støttet af en konsensus mellem ham og hans tilhørere." (Pratt 136; min kursiv.) ${ }^{\mathrm{r}}$

Pratt holder sig ikke tilbage for at placere dette talerens og tilhørernes engagement $i$ et kultur- og antropologisk perspektiv:

"De fleste vil være enige i, at den her slags fremstilling og fremvisning af oplevelser er en fundamental menneskelig aktivitet, en, der er af afgørende betydning for vort velbefindende i verden, og som giver en uendelig nydelse. En af de vigtigste måder, vi har for at respondere på uventede, uvisse, ubegribelige aspekter af vore liv på, er at dele dem med andre og fortolke dem kollektivt. At udføre denne kreative, fortolkende proces er en af de vigtigste måder at bruge sprog på.” (I40)

Så det, fortælbare fortællinger gør, er kort sagt at præsentere og gøre andre delagtige i oplevelser, experiences, som tilbydes for konsensusskabende overvejelser og diskussion. ${ }^{2}$ Pratt vil gerne give en præcis karakteristik af denne "verbale oplevelses-præsenterende og oplevelses-delagtiggørende aktivitet [this verbal experience-displaying, experience-sharing activity]" (I40). Men skønt hun endnu, siger hun, er langt fra at være der, er det ikke desto mindre klart, at litterare værker, "eller i alt fald virkelig mange af dem", er eksempler på denne aktivitet.

To bemærkelsesværdige træk ved display-teksters rolle i konversationskontekster viser sig nu at være vigtige i en betragtning af "litterære værker" som display-tekster (I43). Det første træk er, at teksterne kan frakobles deres umiddelbare kontekst, for de kan nemt indføres i en konversation næsten uden tilknytning til, hvad der ellers bliver talt om, og de behøver ikke adressere tilhørernes umiddelbare interesser eller bekymringer. "Den eneste tilhørerbaserede hensigtsmæssighedsbetingelse for display-tekster er, at tilhøreren er i stand til at anerkende og sætte pris det fortaltes fortælbarhed" (I45). Sådanne tekster er altså ikke primært relevante eller interessante for tilhøreren på grund af deres informationer. "Ligesom med udråb kræves der ikke af en naturlig fortæller, at han er informativ" (I47). Implicit i disse

I Pratts idé om showing kan umiddelbart synes at være lidt afvigende i forhold til Lubbocks. Pratt påpeger, at traditionel grammatik har leveret en distinktion mellem to typer "påstande". Udråbssætninger [exclamatory assertions] (af typen "Åh, det er sgu varmt i dag!") er per definition påstande, som viser sagsforhold, idet de præsenterer dem for deres fortælbarhed. Udråbssætninger er upassende [inappropriate], medmindre de leverer information, som taleren mener er usædvanlig eller uforventet. "Udråbssætninger må være fortælbare," men de behøver ikke levere ny information, det er nok, at de er usædvanlige eller problematiske (I37). Ofte har de også den funktion at annoncere en efterfølgende display-tekst. Imidlertid, hos Lubbock forekommer udråb som del af en karakters tale, altså i den fiktion, som showing er et væsentlig kendetegn for. Der er ingen afvigelse her; det er den (hos Pratt) uartikulerede forskel på et lingvistisk og et narratologisk perspektiv, der får det til at se sådan ud.

2 Det er ikke utænkeligt, at vi her finder en væsentlig inspirationskilde til Monika Fluderniks begreb om den experientiality, som for hende præger fiktionsværker, skønt hun nok ikke - bortset fra en genbrug af Pratts indledende titelord med en let ændring (Toward > Towards) i titlen på sit eget hovedværk (Fludernik 1996)) - giver Pratt den plads og betydning, hun rettelig fortjener. 
formuleringer ligger en antagelse om, at display-tekster bryder ud af den kontekst, de optræder i, og i stedet så at sige skaber deres egne kontekstuelle omgivelser. - Det andet træk er, at vi elsker at variere og ændre i teksterne. Gentagelser og variationer er ikke bare mulige, men i høj grad ønskelige.

Pratt noterer, lidt rundhåndet måske, at de fleste litterater er fortrolige med at betragte litterære værker som display-tekster indrettet på at "genskabe, fortolke og evaluere oplevelser”, men tilføjer:

"Den væsentlige pointe [...] er, at denne re-kreative, interpretative aktivitet ikke er unik for litteratur. I alt fald er både litterære og naturlige fortællinger eksempler på den. Det vil sige, at disse to ytringstyper i stort omfang udnytter de samme aspekter af vor lingvistiske kompetence. [...] Den slags relation, der udfoldes mellem læser og litterært værk, behøver ikke og kan ikke ses som resultat af en suspension af eller immunitet over for de regler, der styrer andre diskurser; snarere er det en relation, der i almindelighed karakteriserer diskurs uden for litteratur og som dér kan forklares ved de generelle regler for tale, snarere end ved særlige regler for litterær diskurs" (I49). ${ }^{3}$

Det kunne således være nærliggende at spørge, om Pratts beskrivelse af de narrative display-teksters pragmatik egentlig ikke også kunne være en præcis beskrivelse af den narrative fiktionalitets pragmatik, så vel uden for som inden for litteraturens kanoniserede område. Pratt leger faktisk med den tanke, men forkaster den med den nøgterne begrundelse, at "distinktionen mellem fiktion/ikke-fiktion er hverken så klar eller så vigtig som man kunne tro, i alt fald ikke i det fortælbares rige. Vor evne til at præsentere og evaluere oplevelse og finde nydelse ved display-tekster kan lige så gerne anvendes på oplevelser, som gør krav på at være virkelige, som på sådanne, som ikke gør det” (I43). Hvem kan være uenig i det? - lige bortset fra, at hvis det for forfatteren er sådan, at det er oplevelsen, der gør krav på at være virkelig, er det for tilhøreren eller læseren nok snarere display-teksten, der på sin vis gør krav på det oplevedes virkelighed - ved at "vise" den. Fortællende tekster, der ikke gør dét, ville netop ikke være display-tekster.

\section{Richard Walsh og fiktionalitetens retorik}

Pratts bog repræsenterer på mange måder den lingvistisk-pragmatiske baggrund for Richard Walshs The Rhetoric of Fictionality (2007). Walsh bygger her videre på Pratts ansatser, men han kan desuden, (I) inddrage narratologiske værker, som Pratt i I977 ikke var bekendt med, (2) respondere på enkelte fiktionsteoretiske perspekti-

3 Pratt er mig bekendt i sine senere arbejder, som primært består af omfattende sociolingvistiske undersøgelser, ikke vendt tilbage til den litterære tematik. Jeg kan alligevel ikke undlade at nævne den meget læseværdige artikel "Ideology and Speech-Act Theory" (Pratt I986), som skarpt og gnistrende ironisk kritiserer visse ideologiske sider af sproghandlingsteoriens overvejelser. Her finder man $\mathrm{i} ø v$ rigt et for lingvister usædvanligt varmt forsvar for Derridas kritik af Searle (Derrida 1966). Et lignende forsvar for Derrida findes i Walsh Novel Arguments 6-8. 
ver efter 1977, og endelig (3) knytte an til den revolution af retorikkens teori, der blev igangsat af Dan Sperber og Deirdre Wilsons kognitionsteoretisk inspirerede relevansteori i Relevance, Communication \& Cognition (I995).4 Det følgende er en (alt for) kort og selektiv gennemgang og diskussion af kapitel i i Rhetoric, som i dansk oversættelse hedder "Den narrative fiktionalitets pragmatik" (jf. Walsh i foreliggende nummer). Denne tekst har en stor rigdom af informationer og antagelser og er, sådan som jeg læser den, meget fortættet i sin argumentation; til tider kan det være svært at finde ud af, hvad der er præmisser og hvad der er konklusioner, visse udtryk bliver først forklaret til sidst, og en række formuleringer er så prægnante, at de kan invitere til at blive husket og citeret, selv når deres placering og funktion $\mathrm{i}$ tekstens argument ikke er lysende klart. I min gennemgang forsøger jeg derfor (og det er kun et forsøg) at udrede noget af tekstens logiske sammenhæng og dermed også pege på visse aspekter, som Walsh ikke nævner eksplicit, men som muligvis kan bidrage til dens baggrundsbelysning, hvis man kan sige det sådan.

\section{Fiktion versus ikke-fiktion}

Europæisk kultur har fra Aristoteles arvet en fundamental distinktion mellem fiktion og ikke-fiktion. Set i et kulturhistorisk perspektiv har distinktionen indlejret sig i almindelig sprogbrug og en praktisk viden i kulturelle institutioner og sædvaner, bibliotekernes klassifikationssystemer, for eksempel, eller forlagenes redaktions- og anmeldere og underviseres ordbrug. Men denne helt afgørende forskel mellem fiktion og ikke-fiktion er til gengæld ikke nødvendigvis en, der er praktisk på den måde, at den viser sig eller lader sig aflæse af fortællingerne selv; den foreligger (hvis overhovedet) først og fremmest som en kontekstuel viden produceret ved paratekstuelle markeringer i romaner og noveller (i engelsktalende lande for eksempel ved betegnelsen "fiction"), eller ved teksternes placering i bibliotekernes kartoteker og boghandlerens hylder eller i form af anmeldere eller litteraturhistorikeres bemærkninger om dem: et rudimentært praktisk system af vejvisere, som man i dag i det store og hele (men ikke altid) kan stole på. Systemet er et generisk system, det ser fiktion og ikke-fiktion som to forskellige litterære genrer. Problemet med et sådant klassificerende system er, som Walsh ser det, at det er for labilt til at generere begreber og termer, som er skarpe og relevante nok til at fungere effektivt og opklarende i moderne litteraturkritik eller i teoretiske diskussioner. Det har for eksempel ikke kunnet forhindre, at "fortælleteoriens interdisciplinære ambitioner" tenderer mod at "sammensmelte fiktionalitet med en generel idé om narrativitet, som omfatter ikke-fiktionale fortællinger", eller at teorien om fiktionale verdener "har forsøgt at afvæbne fiktionalitet ved at bogstaveliggøre fiktional reference". (The Rhetoric of Fictionality 38) Walshs modspil til disse

4 Wilson \& Sperber (20I2) udvikler og "opdaterer" pointerne fra denne bog i en artikelsamling. Bemærkelsesværdigt nok finder man her ingen referencer til Walsh: Kommunikationsteori kommunikerer åbenbart dårligt med litteraturteori. 
tendenser består i at se fiktionalitet som en retorisk størrelse. Hvad det indebærer, bliver skarpt præciseret i 2. kapitel af Rhetoric, som jeg her vil bringe et længere citat fra, dels for at vi ikke skal glemme det igen, dels fordi det her bliver tydeligt forklaret, at formålet med et retorisk begreb om fiktionalitet er at udmanøvrere betydningen af 'fiktion' som genrebegreb:

"Idet jeg taler om kvaliteten fiktionalitet, iscenesætter jeg argumentet på et skridts afstand fra den generiske distinktion mellem fiktion og ikke-fiktion [...], men fiktionalitet er selvfølgelig en egenskab ved alle fiktioner i den forstand, eftersom den kan anvendes på alle fortællinger, der skønnes at være fiktionale (til forskel fra falske): som sådan er den en fortolkningsramme, som bøjer og transformerer hele den narrative forståelsesproces. [...] En retorisk definition af fiktionalitet er pragmatisk derved, at dens kriterier i sidste instans ikke er inhærente i fortællingen selv, men er kontekstuelle. Fiktionalitetens retorik bringes i spil, hver gang en fortælling tilbydes eller tages som fiktion, uafhængig af spørgsmål om form, stil eller reference. Selvfølgelig er det sådan, at de fleste fiktioner faktisk fremviser egenskaber, som indikerer deres fiktionale status [...] men disse er hverken nødvendige eller tilstrækkelige betingelser for fiktionalitet. Og det skyldes ikke kun sådanne indikatorers historisk varierende status, skønt nogle af dem faktisk i tidligere tider har været accepteret som konventionelle tegn på historicitet: for eksempel var visse effekter af narratorial alvidenhed, blandt andet ubevidnede monologer, accepterede manifestationer af autoritet i den heroiske historiefortælling (Scholes og Kellogg 266). Men selv i den velkendte, moderne fiktionskontrakts termer har fiktionalitet ingen bestemt relation til træk i teksten selv. For eksempel kan fiktion udmærket klare sig uden dækket direkte tale [free indirect discourse], og ikke-fiktion (lad os sige en biografi) kan benytte sig af den. [Dækket direkte tale er altså ikke en nødvendig betingelse for at antage, at en tekst er fiktion.] Nutidige læsere vil givetvis opfatte forekomsten af dækning i en ikke-fiktional fortælling som noget af en frihed, men det gør ikke teksten til fiktion (faktisk bekræfter det snarere, at deres interpretative holdning til den indebærer, at den bliver opfattet som ikke-fiktion). Af samme grund kan fiktionalitetens principielle adskillelse fra enhver tekstuel indikator udvides til spørgsmålet om reference. Hvis en fortælling, der tilbydes som historisk, viser sig at være inkonsistent med dokumenterede kendsgerninger, endog i en sådan grad, at det drejer sig om referencesvigt (hvis den for eksempel har interpoleret en ikke-eksisterende karakter i fortællingen), da bekræfter det - netop fordi denne fejl eller dette kneb bliver stillet til ansvar over for en historisk falsificerbarheds kriterier - at teksten ikke er fiktion, men kompromitteret historie. [En fiktiv karakter er altså ikke en tilstrckkelig betingelse for at slutte, at teksten er fiktion.]

Det kategorisk distinktive ved fiktionalitet indebærer ikke et alt-eller-intet-syn på en fortællings forhold til verificerbare fakta. Fiktioner er ofte ikke fuldstændig fiktionale, og i princippet behøver de ikke være fiktionale overhovedet. Der er forskellige omstændigheder, hvor ikke-fiktionalt materiale, hvad enten det er tilkendegivet (den historiske roman), eller hemmeligt (nøgleromanen) eller fuld- 
stændig tilfældigt, kan bebo en fiktional fortælling. Men disse omstændigheder, og de sammensatte motiver, som de to førstnævnte implicerer, er konsistente med en fortællings [...] krav på at blive modtaget og fortolket under fiktionalitetens regime. Ligeledes hænger en pragmatisk tilgang til fiktionalitet ikke det kategorisk absolutte op på nogen som helst form for ahistorisk essens: Ikke alene bliver fiktionens konventionelle former udsat for forandringer, men både fiktionalitetens rækkevidde og dens betydning er historisk og kulturelt variable.

Fiktionalitet er et produkt af en fortællings præsentationsramme, af de forskellige mulige elementer af hvad Gérard Genette har beskrevet som parateksten. Distinktionen mellem fiktion og ikke-fiktion hviler på den retoriske brug, som en narrativ tekst anvendes til, hvilket vil sige: arten af den interpretative respons, den inviterer til, idet den præsenteres som det ene eller det andet. Og distinktionen er kategorisk, ikke fordi der er definerende egenskaber, der er inhærente i nogen af dem, men fordi de interpretative operationer, der kan anvendes på en fortælling, på den ene eller på den anden måde ændres globalt af den ydre, kontekstuelle ramme, i hvilken fortællingen modtages." (Walsh The Rhetoric of Fictionality 44f.) ${ }^{5}$

Et par mere eller mindre skæve kommentarer er måske på sin plads her: Walsh opererer - heuristisk - med en fundamental forskel på fiktivt og ikke-fiktivt "materiale”. Denne forskel er generisk, og det er i princippet den, som i dag styrer forlagenes og bibliotekernes klassificering af narrative tekster. Men hvis der opstår tvivl, hvilket nemt kan ske, hvor teksterne blander genrerne, kan man følge disse praktiske regler: En tekst, der rummer en eller anden mængde af ikke-fiktionalt materiale, kan under visse omstændigheder fastholde sit "krav på” at blive modtaget og fortolket under "fiktionalitetens regime". Omvendt kan en ikke-fiktional teksts anvendelse af visse greb og teknikker, som læsere kender fra fiktionale tekster, og som derfor kan vække tvivl om dens status som ikke-fiktional, så at sige pragmatisk få sin status bekræftet, idet netop læsernes tvivl viser, at teksten faktisk bliver opfattet som ikke-fiktional. Overvejelser som disse kunne faktisk optræde i en manual til vejledning af f.eks. bibliotekarers sorteringsarbejde. Det er derfor, de er "pragmatiske" ("pragmatisk" har mange betydninger). Men de udmanøvrerer ikke det generiske klassifikationssystem. Snarere forklarer de, hvordan systemet fungerer i praksis. Udtryk som "fiktionalitetens regime" er i den forstand kun et andet navn for den generiske kategori "fiktion", skønt ordlyden antyder noget mere end et skrøbeligt fiktionsbegrebs konventionelle og forslidte sikkerhed, nemlig et magtforhold: Et moderne regime beholder sin magt ved at forhandle om sine grænser og beføjelser. Men denne "Foucaultske” pointe er ikke Walshs, og han tænker næppe "fiktionalitetens regime" som et genreregime. Min kommentar har trukket Walshs tekst en smule ud af kontekst her, for konteksten er sat med

5 Når jeg i det følgende bruger termerne "fiktioner", "fiktionsfortælling", "fiktionssætning" o.l., skal det selvfølgelig ikke forstås som genrebetegnelser, men som pragmatiske termer - medmindre konteksten indikerer noget andet. 
bemærkningen om, at "en retorisk definition af fiktionalitet er pragmatisk derved, at dens kriterier i sidste instans ikke er inhærente i fortællingen selv [hvilket er antagelsen i alle klassiske genreteorier], men er kontekstuelle”, det vil sige: givet ved de paratekstuelle markeringer, som det institutionaliserede generiske system producerer, hvilket så gør, at fiktionalitetens retorik kan sættes ”i spil hver gang en fortælling tilbydes eller tages som fiktion”. Det er altså fiktionalitetens retorik, der udmanøvrerer genreteoriens overvægt på fiktionsteoriernes slagmark. Walshs bedste våben er antagelsen om, at i et pragmatisk-retorisk perspektiv hviler distinktionen mellem fiktion og ikke-fiktion på den retoriske brug af tekster, det vil sige den respons, de inviterer til, når de udgives som det ene eller det andet. Det er denne dristigt balancerende, dialektiske ouverture til et retorisk begreb om fiktionalitet, der bliver gennemspillet for fuld udblæsning i kapitel I af Rhetoric, som ikke alene søger at etablere et retorisk begreb om fiktionalitet, men endog (som jeg ser det) en teori $^{6}$ om fiktionalitetens pragmatik, dens praktiske retoriske virkningsfuldhed. ${ }^{7}$

\section{Fiktionalitet og kommunikation}

Ligesom Pratt undersøger display-teksters kommunikative funktioner og egenskaber, undersøger Walsh fiktionstekster, og fiktionalitet i det hele taget, som noget, der er intimt forbundet med sprog. Dette til forskel fra "moderne redegørelser for fiktionalitet", som generelt drejer sig om "et eller flere i et lille repertoire af teoretiske åbningstræk, der samlet kan forstås som fornægtelsesgestus", for de "ser fiktionalitetsproblemet som et spørgsmål om sandfærdighed og løser det ved at afkoble den fiktive akt fra sandhedens område, det vil sige: sproget" (I4f.; 20I3: II). Over for denne ringeagt for sprogets betydning foreslår Walsh: ”Fiktionalitet [...] er noget, der fungerer i et kommunikativt netværk; [og som] findes i en måde at bruge sprog på, og dens særegenhed består i det genkendelige retoriske sæt, ${ }^{8}$ som denne sprogbrug kalder på” (I5; 2013: II). Som en slags sidebemærkning tilføjer han: "Jeg antager, at narrativ fiktionalitet er værd at skelne fra narrativitet i almindelighed. Det vil sige, jeg ønsker at anerkende den fulde kraft i hævdelsen af, at enhver fortælling forudsætter en vis kunstfærdighed [artifice], og at den i denne meget begrænsede forstand er fiktiv" (I5; 20I3: II). Men hvis enhver fortællings kunstfærdighed indebærer, at den i meget begrænset forstand er fiktiv (et synspunkt, der fejlagtigt er blevet taget som bevis på, at Walsh skulle være "panfiktionalist"), da er dét ikke noget, der kan bidrage til at skelne narrativ fiktionalitet fra narrativitet $\mathrm{i}$

6 Med teori mener jeg her et system af velbegrundede og logisk sammenhængende antagelser, der ikke længere med rimelighed kan betragtes som blot et system af udskiftelige hypoteser. Det udelukker ikke, at teorier kan forbindes og uddybes med nye antagelser, blot at disse ikke længere kan forventes at erstatte teoriens kernebegreber.

7 Det ville være interessant at undersøge - $\mathrm{i}$ lys af Walshs teori (og til historisk belysning af den) - hvilken rolle sammenstødet mellem klassisk retorik, platonisk inspirationsæstetik og renæssancens genopdagelse af Aristoteles' Poetik spiller i tilblivelsen af fiktionalitetens genreteoretiske regime i perioden ca. 1450 til ca. I75O. (Jf. Anne Duprat 2008.)

8 (Jf. note 24 nedenfor) 
almindelighed, og Walsh bruger det da heller ikke til noget i dette kapitel. Det, det her drejer sig om, er, at et begreb om en generel narrativitet æder spørgsmålet om fiktionalitet; det skubbes i baggrunden for narrative problematikker. Walsh ønsker derimod at stille det i forgrunden, for "den fiktionale fortælling har en kohærent og distinkt kulturel rolle, og der kraves et distinkt begreb om fiktionalitet for at gøre rede for denne rolle" (I5; 20I3: II, min kursiv). Så dét er opgaven, som Walshs bog skal bidrage til at løse: At levere et distinkt begreb om fiktionalitet, der kan redegøre for fortællingers kohærente og distinkte kulturelle rolle.

Det kræver et par indledende teoretiske markeringer:

"[Fiktionalitet] forklares bedst i funktionelle og retoriske termer, og ikke i formale termer: Sandt nok, der er formale kvaliteter, der er stærkt associeret med fiktion, men disse leverer ikke nødvendige eller tilstrækkelige betingelser for fiktion. Siger man i stedet, at fiktionalitet er en funktionel egenskab, indebærer det, at den er en sprogbrug; at sige, at den er retorisk, vil sige, at denne sprogbrug udskiller sig ved den måde, hvorpå den appellerer til læserens (eller publikums) fortolkende opmærksomhed." (I5; 20I3; II)

Formale egenskaber er, hvad narratologien traditionelt beskæftiger sig med: fortællepositioner, forholdet mellem story og diskurs, fokaliseringer, deiksis, plotstrukturer, direkte, dækket direkte og indirekte tale etc. Disse egenskaber forklarer ikke fiktionsspørgsmålet. Men siger vi, at fiktionalitet er en funktion af sprogbrugen, sprogets pragmatiske dimension, sådan som den forstås i sproghandlingsteorien, giver det os en mere oplagt mulighed for at forklare fiktionalitet $i$ en kommunikativ sammenhang og producere et distinkt begreb om dens kulturelle rolle - dog kun, hvis vi også bringer sprogbrugens retorik på banen: Sproghandlinger er henvist til at følge visse regler for at være effektiv kommunikation; sprogbrugens retorik handler derimod om at bruge sproget til at opnå særlige effekter, i det mindste kalde på tilhørernes eller læsernes opmærksomhed, vække og fastholde deres interesse. Pratt opererer måske ikke med en adskilt retorisk kategori, men ideen om fortælbarhed som relevanskriterium for fortælleakten kan sikkert udlægges som et omfattende og klart retorisk begreb: Display-tekster tiltrækker sig netop en "særlig fortolkende opmærksomhed". - Så sprogbrugen og dens retorik: Vi skal efterhånden lære, hvilken hemmelighed denne differerende dobbelthed bærer på.

For at profilere sin position vælger Walsh nu at forberede en konfrontation med en fristende "moderne redegørelse" for fiktionalitet, nemlig teorien om fiktionale verdener:

"Ingen model, der behandler fiktiv diskurs som indrammet af en formal, intentional eller ontologisk fornægtelse, kan tilfredsstille [de før nævnte] kriterier for et begreb om fiktionalitet. Hvis fiktionalitet består i en [retorisk] distinkt måde at bruge sprog på, bliver den ikke forklaret ved at sammenkoble denne distinkthed med en eller anden karantæne-mekanisme, hvis formål netop er at opretholde en 
konformitet med ikke-fiktional sprogbrug, men med den omkostning, at den på den ene eller anden måde afkobles fra sin aktuelle kommunikative kontekst. Så det retorisk distinkte ved fiktion er konsistent med en kommunikativ kontinuitet mellem fiktional og ikke-fiktional sprogbrug. Fiktionalitet er en retorisk ressource, en integrerende del af direkte og seriøs sprogbrug inden for den virkelige verdens kommunikative rammer." (I5f.; 20I3: IIf.; mine kursiver)

Den sidste sætning er en af disse prægnante sætninger, som bliver husket og ofte citeret. Og det er der gode grunde til, for dens kraft skyldes ikke mindst, at den indtager en samlende retorisk nøgleposition i tekstens argument. (Om lidt skal vi undersøge den tilsyneladende umotiverede brug af termen "retorisk ressource".) Argumentet indledes tidligt med et spørgsmål - i et afsnit, der samtidig annoncerer et teoretisk fokusskift:

"Hvis den narrative repræsentations logik ikke leverer en forsvarlig distinktion mellem fiktion og ikke-fiktion, da forskydes den teoretiske opmærksomheds fokus med nødvendighed fra den fiktionale fortællings substans til den fiktive fortælleakt, fra fiktionsproduktet til produktionen af fiktion. Hvordan skal vi forstå fiktiv narration som en referentiel akt eller som en kommunikationsakt?" (I4; 2OI3: IO, min kursiv)

Dette citats sidste sætning er, hvad jeg vil kalde en signalsætning: Den stiller et spørgsmål og lover indirekte, at det vil blive besvaret senere. For at følge argumentet, er jeg nødt til springe over kapitlet "Relevans og fiktionale verdener" og gå direkte til det næste kapitel, hvor vi i første omgang møder en anden argumentationslinje.

\section{Fiktionens forfatter fingerer ikke; han fortceller virkelig en historie}

Richard Ohman og John Searles standardredegørelse for "litterær diskurs" er imitations-talehandlingens model, hvor forfatterens tale ikke er seriøst ment, men fingeret. Walshs hovedkritik af denne model er enkel: Den undermineres af det faktum, "at tredjepersonsromaner rutinemæssigt afviger fra normer, der gør sig gældende i enhver ikke-fiktional talehandling i den virkelige verden, for eksempel i noget så almindeligt som en alvidende narrations strategier". 9 Modellen redegør således ikke for fiktionalitet, "for fiktionalitetens retorik er ofte selve narrationen iboende":

"Den første sætning i mit citat fra Processen, for eksempel, yder modstand mod at blive restitueret som en fingeret ikke-fiktional sproghandling, både hvad gælder

9 Tredjepersons fiktionsfortællingers "rutinemæssige afvigelse" fra ikke-fiktionale fortællingers normer er altså et tegn på fiktionalitet. Det betyder selvfølgelig ikke, at enhver sådan afvigelse også er det. 
dens indhold (adgang til en andens tanker) og dens form (den indre fokaliserings dobbelte tidslighed, manifesteret i det ellers anomale 'nu')." (20; 20I3: I6, min kursiv)

Argumentet er forbløffende simpelt. Searles opfattelse modsiges med henvisning til et stykke fiktionsfortælling - et empirisk argument. Men det støttes af et andet argument, som er teoretisk: En fingeret talehandling placerer sig på kanten af eller uden for de normer og regler, der gælder for normalsproget; normale betingelser for en talehandlings vellykkethed gælder ikke her. Hvis vi derimod antager, at fortællinger, der allerede antages at levere fiktioner, består af seriøse talehandlinger som altså ikke fingerer at fortælle en ikke-fiktional historie - får vi et helt andet perspektiv på spørgsmålet om fiktionalitet, og faktisk en dobbelt gevinst: For det første er der grund til at antage, at antagelsen om fiktionalitet ikke længere vil støde på modstand fra fortællingerne selv, for de vil ikke længere være forpligtet på normer, der gælder for ikke-fiktionale fortællinger. (Således får vi også mulighed for at se fiktionalitetens retorik.) Til gengæld bliver enhver antagelse, der implicerer, at fiktionstekster med nødvendighed overskrider normer for normalsproglige talehandlinger, overflødig. ${ }^{\text {Io }}$ Så hvad er Walshs alternativ til Searle? Vi kender det allerede:

"Fiktionalitet er en [...] integrerende del af direkte og seriøs sprogbrug inden for den virkelige verdens kommunikative rammer." (I5f.; 20I3: I2)

Med undtagelse af det, jeg lige har gemt i den kantede parentes, drejer det sig her altså om en ren negation af Searles opfattelse, eller - hvis jeg må låne en vending af Freud - en omvending til det modsatte: Searle siger, at forfatteren fingerer, at han fortæller en ikke-fiktiv historie; Walsh argumenterer, at forfatteren ikke fingerer, men seriøst og inden for den virkelige verdens kommunikative rammer bare fortæller en fiktiv historie, altså leverer en fortælling, som ikke handler om virkelige personer og begivenheder.

Men så er der altså den tredje mulighed, nemlig den, at forfatteren i fiktioner seriøst og inden for den virkelige verdens kommunikative rammer - faktisk refererer til personer og begivenheder, blot befinder disse sig i fiktionale verdener. Og det er end ikke en ualmindelig opfattelse: Hvad skulle forfatteren ellers referere til, når han i fiktioner per definition ikke refererer til den virkelige verden? Walsh anlægger dog en anden vinkel - med begreberne om relevans og publikums fortolkende dagsorden som formidlende instanser:

"Begrebet om relevans optræder [...], inden for to distinkte, velafgrænsede teoretiske domæner, som har været vigtige for de seneste diskussioner om fiktionalitet: Det ene er teorien om fiktionale verdener, der fokuserer $p a ̊$ den referentielle akt; det andet

IO På dette sted i teksten laver Walsh en længere digression om Genettes idé fra 1990 om indirekte talehandlinger, som jeg ikke vil kommentere her, da det ser ud til, at han ikke rigtig bruger den til noget. Se i øvrigt Simona Zetterberg Gjerlevsen 2013: "En seriøs sprogteoretisk fiktionalitetsdefinition" (i foreliggende nummer). 
er sproghandlingsteorien, i særdeleshed de redegørelser, der giver sig i kast med Grices "konversationelle implikatur" [...] hvor fokus er på den kommunikative akt." (I6; 2013: I2, mine kursiver)

Så hvordan skal vi forstå fiktiv narration - som referentiel akt, eller som kommunikationsakt? Svaret kan i første omgang udlæses af det konkluderende afsnit i det kapitel om relevans og fiktionale verdener, som jeg har sprunget over:

"I teorien om fiktionale verdener er relevansbegrebet knyttet til to antagelser, som jeg ønsker at modsætte mig: den ene er, at fiktionens "fakta" [som narrative tekster angiveligt refererer til] er meningsfuldt uafhængige af relevansbetragtninger; den anden er, at relevans er noget, der findes inden i den fiktionale verden, at den altid kan betyde noget uafhængigt af den kommunikative akt. Min modsatte påstand er, at læserens interpretative dagsorden [som er den, der mest umiddelbart bringer relevansspørgsmålet på banen] ikke kan forstås inden for en afgrænset fiktional verden, og da slet ikke i relation til dens fiktionale eksistens frem for dens aktuelle kommunikation, [...]. (Walsh The Rhetoric of Fictionality: 20; 2013: 15f.)

Walsh siger her ganske vist ikke helt direkte og utvetydigt, at fiktioner kun består af kommunikationsakter uden referencefunktion. (Vi skal senere se, hvad der måske er grunden til denne forsigtighed.) Men idet han modsætter sig den opfattelse, at den fiktionale fortællings "fakta", herunder dens story, skulle eksistere i den fiktionale verden uafhængigt af læserens relevansstyrede fortolkninger, da har han næsten sagt, at en fiktional fortælling ikke har brug for at referere til det, den fortæller om. Jeg tror, hovedpunkterne i kritikken af teorien om fiktionale verdener kan sammenfattes på følgende måde: Teorien om fiktionale verdener kan ikke gøre rede for fiktionalitet, eftersom den fokuserer på referentielle spørgsmål og åbenbart ikke har brug for at stille spørgsmål om den for fiktionaliteten specifikke, aktuelle kommunikative kontekst (som omfatter den kontekstuelt givne antagelse om fiktionalitet, samt fiktionalitetens distinktive retorik, den måde, som fiktional fortællen appellerer til publikums fortolkende opmærksomhed på). Til gengæld har fiktiv narration ikke brug for at referere til fiktive personer og begivenheder.

På den baggrund kan vi nu også bedre forstå udtrykket "fiktionalitet er en retorisk ressource": Ordvalget responderer på, at teorien om fiktionale verdener har sine ressourcer; det kunne for eksempel være det fascinerende ved ideen om imaginære verdener, hvis personer og begivenheder er som i en virkelig verden, og som man kan visualisere, forestille sig, referere til og tale om: imaginationens ressourcer, måske. Men disse gør ikke rede for fiktionalitet, for de afkobler fiktionaliteten fra dens kommunikative kontekst og retoriske ressourcer.

I tilbageblik kan vi således se, hvordan nøglesætningen "Fiktionalitet er en retorisk ressource, en integrerende del af direkte og seriøs sprogbrug inden for den virkelige verdens kommunikative rammer" er et dobbelt, samlende resultat, dels af omvendingen af Searles forestilling om den fingerende fortæller, dels af afvisningen af teorien om 
fiktionale verdener. Sætningens tidlige placering i teksten er misvisende, hvis den tages som indikation på, at den bør opfattes som en præmis for det efterfølgende. Præmissen, eller udgangspunktet, er snarere den påstand (eller antagelse), at fiktionalitet er en funktionel egenskab, en funktion af den måde, sproget bruges på, og at denne sprogbrugs retorik udskiller sig ved den måde, hvorpå den appellerer til læserens (eller publikums) fortolkende opmærksomhed. Nøglesætningens prægnante formulering er et resultat af denne præmis' konfrontation med et par fremtrædende alternative forsøg på at gøre rede for fiktion. I den forstand er dens tilblivelse tillige en afgrænsningsmanøvre: Den definerer det felt, som undersøgelsen af fiktionalitetens retorik skal bevæge sig inden for, eller sagt med Walshs ord: den definerer et distinkt begreb om fiktionalitet for at forklare den fiktionale fortællings kohærente og distinkte kulturelle rolle.

Men der er stadigvæk nogle løse ender i dette foretagende. Vi har set, hvordan begrebet om relevans ligesom bliver spillet ind fra sidelinjen, og Walsh har endnu ikke direkte og utvetydigt udtalt, at fiktionsfortællinger ikke refererer til noget, skønt implikationen synes klar. Lad os forsøge at gøre den eksplicit, idet vi inddrager nogle ressourcer, som måske hører til blandt Walshs kognitive omgivelser. Det giver os desuden en chance for at hente nogle ekstra gevinster.

\section{Relevans, ikke reference: Den antimimetiske position}

Dorrit Cohn, en af de få narratologer, der har forsøgt at fastholde Hamburgers genreorienterede fiktionsbegreb, ", bruger gerne paradoksale formuleringer af typen "Fiktionsfortællinger skaber den verden, de refererer til, ved at referere til den". Dette er også en fundamental pointe for Walsh, men med den væsentlige modifikation, som vi har set, at det, der skabes i fiktionsfortællingen, ikke er en verden af fiktive personer og begivenheder. Lad os derfor uden videre postyr slå fast: For Walsh er det sådan, at hvis en referentiel sproghandling refererer til noget, der må antages at eksistere før og uafhængigt af sproget, så refererer fiktionens sproghandlinger ikke til noget, der eksisterer uafhængigt af handlingerne; kort sagt, de refererer ikke til noget, ej heller til fiktionale ting i fiktionale verdener.

Et par punkter er måske værd at nævne her, eftersom de kun befinder sig i baggrunden af Walshs diskurs i dette kapitel om den narrative fiktionalitets pragmatik. Walshs position i referencespørgsmålet skriver sig ind i en længere filosofisk diskussion om reference-begrebet og et urgammelt problem i filosofihistorien: Kan man overhovedet referere til noget, der ikke eksisterer? (Jf. Crittenden I99I). ${ }^{\mathrm{I}}$ I en fiktionsdiskussion bliver spørgsmålet akut: Hvis man taler om, at fiktionssætninger refererer til noget, giver man plads til at opfatte forholdet mellem tekst og det, teksten angiveligt refererer til, som et mimetisk forhold, således at teksten på en eller anden måde skulle efterligne, gengive eller repræsentere det fortalte. Walsh,

II Jf. Cohn I999.

I2 Se også analysen af Gorgias' Palamedes' forsvarstale i Henrik Skov Nielsen 2003. 
som allerede i sin første bog, Novel Arguments (I995), ${ }^{13}$ tilslutter sig den antimimetiske traditionslinje, finder denne urgamle, men ret platte fortolkning af mimesis meningsløs og vildledende. Som Genette siger (citeret efter hukommelsen), idet han formulerer sin antimimetiske position: "Ord kan ikke efterligne andet end ord" (jf. Genette Narrative Discourse I63f.). Og narrative fiktioner består af ord og deres mulige betydninger. Dét er så også, hvad forfattere "skaber", og ikke fiktionale verdener eller fiktionale objekter. ${ }^{\mathrm{I} 4}$ Alene af denne position følger, at fiktioner, alt andet lige, ikke opererer med egentlige referencer (det ville i alt fald kræve støtte fra et helt apparat af tillægsantagelser for at bygge en fiktional, referentiel verden). ${ }^{5}$ Hvis omvendingen af Searles antagelse om fiktionsforfatterens fingeren er et afgørende, men ikke chokerende, moment i Walshs fiktionalitetsteori, kan jeg nemt forestille mig, at antagelsen om, at narrative fiktioner egentlig ikke refererer til noget, blandt narratologer vil blive modtaget med en vis bestyrtelse, og blandt lingvister som en bekræftelse på, at fiktionsspørgsmål falder uden for lingvistikkens område. ${ }^{16}$ Den er ikke desto mindre (eller den kan i alt fald konstrueres som) en logisk konsistent slutning ud fra kritikken af Searle og teorien om fiktionale verdener samt de antimimetiske antagelser, jeg lige har nævnt.

\section{Relevansteorien}

I et logisk og epistemologisk perspektiv er det måske noget af en selvfølgelighed at sige om påstande, der refererer til den virkelige verden, at det er relevant at forholde sig til påstandens sandhedsværdi. Men Sperber $\&$ Wilsons nye retoriske teori er en teori om dagligsprogets kommunikative dimensioner og hverken en teori om logik eller om epistemologi. For Walshs formål er den vigtigste konsekvens af denne teori "den nye relation den foreslår mellem relevansfunktioner

I3 Novel Arguments, som leverer en elegant, skarp og informativ analyse af retorikken i ledende litteraturkritikeres reception af nyere "innovative" eller "postmoderne" amerikanske romaner, og som endnu er meget langt fra at henvise til lingvistiske eller kognitivt-retoriske positioner, fokuserer ikke desto mindre (med et begreb om romanens argument) på romanernes effekter på deres læsere. Walsh forstår dette begreb som en måde at forhindre, at romankritikken splittes op i en indre formkritik og en ydre indholdskritik ("ydre" fordi den forudsættes uden hensyn til romanens form - at handle om "virkeligheden". Romanens argument har således nogenlunde den samme funktion som fiktionalitetens retorik tilskrives i The Rhetoric of Fictionality).

I4 Det betyder så også, at hverken Lubbocks eller Pratts distinktion mellem at vise og at rapportere (showing versus telling) implicerer, at læseren bliver vist noget, som hun også bogstaveligt ser. Ej heller handler det om, hvad læseren forestiller sig, men om hvordan hun forstår ordene og deres sammenstilling, og så de fortolkende slutninger, hun drager under læsningen. Men den handler desuden også om noget, der i øvrigt står centralt hos Hamburger, nemlig fortællingers deiktiske funktioner og disses betydning for læserens distance eller engagement. (Jf. udtrykket "deiktisk fokus" (34; 2013: 28). Om Walshs antimimetiske position, se også Reitan.)

I5 Forholdet kan tydeliggøres med Saussures begreber: Ord (signifianter) har betydninger (signifiéer) (semantisk niveau). Ordene kan sammenkædes i meningsfulde sætninger (syntaktisk niveau), uden at ord og sætninger bliver brugt til at referere til noget (pragmatisk niveau). Men i normal sprogbrug udgør referencerne ofte en afgørende pragmatisk dimension. Fiktionalitetens pragmatik er altså i denne forstand en anden end normalsprogets.

I6 Hvad gælder lingvistikken, er der nok ikke de store chancer for, at synspunktet overhovedet vil blive hørt. I The Cambridge Handbook of Pragmatics (Allan og Jaszczolt 20I2), som præsenterer professionelle bidrag fra lingvister af utallige nationaliteter, forekommer der ikke en eneste henvisning til spørgsmålet om fiktion. 
og sandfærdighed i kommunikationen" (Walsh Rhetoric, 26, 2013: 26). Sperber \& Wilson ønsker "at vise, at den funktion, som Grice tilskriver Kvalitetsmaksimerne - at sikre kvaliteten af talerens samlede bidrag - mest effektivt kan opnås i en ramme helt uden en sandfardighedsmaksime"17 (Wilson and Sperber 2002: 585-86, min kursiv). Baggrunden for denne forbavsende påstand er den enkle, at en tanke ofte med fordel kan kommunikeres bedre ved at undlade brug af tankens logiske, propositionale form i kommunikationen (Sperber \& Wilson kalder det tankens bogstavelige udtryk): "der er ingen grund til at tro, at det optimalt relevante fortolkende udtryk for en tanke altid er det mest bogstavelige udtryk. Taleren antages at sigte mod optimal relevans, ikke mod bogstavelig sandhed" (I995: 233, min kursiv.) "Relevansteorien fremsætter den idé, at for kommunikative formål er det propositionale sandhedskriterium underordnet relevansens kontekstuelle, pragmatiske kriterium" (Walsh Rhetoric, 27; 20I3: II, min kursiv). Men dette gælder helt generelt for almindelig, ikke-fiktional hverdagssproglig kommunikation, som trods alt er henvist til at referere til den virkelige verden.

Spørgsmålet om fiktionalitet rejser sig i forlængelse af Sperber \& Wilsons teori på en helt specifik måde:

"Fiktionalitetens problem [er ikke] et spørgsmål om sandfærdighed, men om relevans. Det er formodningen om relevans, ikke en forventning om bogstavelig sandfærdighed, som driver læserens søgen efter en passende fortolkningskontekst. Relevansteoriens model tillader et syn på fiktionalitet, der [ser den som] en kontekstuel antagelse: det vil sige, at i forståelsen af en fiktiv ytring, er den antagelse, at den er fiktiv, selv manifest. Den vigtigste kontekstuelle effekt af denne antagelse er, at implikaturer, der afhonger af bogstavelig sandhed, underordnes implikaturer, som fär relevans på mere diffuse og kumulative måder. Fiktion får ikke relevans [...] ved en eller anden slags analogisk tænkning [hvilket er, hvad Sperber og Wilson foreslår], men gradvist gennem at implicere forskellige kognitive interesser og værdier, som ikke er betinget af en accept af en ytrings propositionale sandhed - og gennem anvendelsen, investeringen og gennemarbejdningen af disse interesser i narrativ form.” (30; 2013: 24, min kursiv)

Når en fortælling antages at være fiktion, overtrumfer altså spørgsmålet om relevans spørgsmålet om referentiel sandhed, som derfor bliver fortolkningsmæssigt irrelevant, hvilket støtter den antagelse, at narrative fiktionssætninger, alt andet lige, ikke refererer, ej heller til fiktionale personer og ting. For Walsh er konklusionen klar:

"En relevans-dreven, pragmatisk fremstilling af inferens i fiktioner behøver ikke udfoldes via en referentiel verden hinsides diskursen eller en denotativ "de re"-

I7 Det drejer sig her om maksimen "Sig ikke, hvad du tror er usandt!". 
semantik hinsides de attributive "de dicto"-relationer mellem refererende udtryk. ${ }^{18}$ [...] Vi er nødt til at tænke i termer om fiktionalitetens pragmatik snarere end i termer om dens semantik.” (32; 2013: 26)

\section{Sammenfatning: Den pragmatiske tilgang, "Hvad foregår der i en fiktiv diskurs?"}

I et forsøg på at sammenfatte sit argument fokuserer Walsh på den måde, hvorpå teorien om fiktionalitetens retorik, i kraft af sin "pragmatiske tilgang", overvinder forskellen mellem indre og ydre relevans og derfor kan gøre rede for, "hvad der faktisk foregår i en fiktiv diskurs”:

"Det [...] indre synspunkt dominerer i de fleste nærlæsninger og i repræsentationsorienteret kritik (hermed mener jeg kritik, der fokuserer på narrative enkeltheder); det andet, det ydre synspunkt, gør sig ofte gældende i formalistiske og læserresponsorienteret kritik (i det mindste for så vidt som de projicerer historier om læsning) og symptomatiske kritikmåder, der trækker (for eksempel) marxistiske, feministiske, psykoanalytiske, queer eller postkoloniale perspektiver ind over teksten. Skønt jeg ikke mener, at der er noget fundamentalt forkert ved nogen af disse tilgange, er der ingen af dem, der faktisk forklarer, hvad der foregår $i$ en fiktiv diskurs. Den første ser det som givet, at vi allerede er bekendte med fiktion (hvilket vi selvfølgelig er), og den anden er tilbøjelig til at sætte fiktionaliteten i parentes for at jagte andre interesser, som den fiktionale tekst giver anledning til. Ved at afvise dualismen af indre og ydre, identificerer en pragmatisk tilgang til fiktionalitet det spørgsmål, som dualismen udvisker. Den står ikke, og bør ikke stå, i modsætning til, hvad vi nu for tiden gør som læsere eller kritikere, men den identificerer noget, som vi ikke gør, og som jeg mener ville være umagen værd. Den udfordrer os til at forklare fiktionalitetens kraft og effekt $i$ vor oplevelse og forståelse af fiktion.” (37: 2013: 3I, mine kursiver)

Fiktionsspørgsmålet træder altså helt i baggrunden i ydre tilgange til fiktioner. I indre tilgange forsvinder det, idet det flyder sammen med et generelt begreb om narrativitet. Den pragmatiske tilgang fastholder det, idet den sætter kommunikationen centralt - eller i forgrunden. Indre-ydre-dualismen udvisker spørgsmålet om fiktion, hvilket for Walsh vil sige: spørgsmålet om den retorik, der appellerer til vor fortolkende opmærksomhed og bevirker fiktionalitetens kraft og effekt i vor oplevelse og forståelse af fiktion. Giver vi derimod afkald på ideen om fiktionens "fiktionale verden", forsvinder forskellen mellem indre og ydre relevans, hvorfor relevansspørgsmålet bliver et, der uden videre handler om, hvordan relevans, nu

I8 de re $=$ om ting, de dicto $=$ om det, der siges. De latinske udtryk bruges i lingvistiske, logiske og metafysiske diskussioner, som Walsh her "kalder på”, men åbenbart ikke bruger til noget, for den sidste del af sætningen (delen med de latinske ord) fordobler bare den første dels indhold: "referentiel verden hinsides diskursen" medmindre termen denotation da skulle være en venlig hilsen til Bertrand Russell (1905), som insisterede på et skel mellem denotation og reference (eksistens). 
primært som kommunikativ relevans, fungerer i produktionen og receptionen af fiktions-diskursen.

Så hvordan forklarer vi, "hvad der foregår i en fiktiv narrativ diskurs"? Og hvordan forklarer vi fiktionalitetens kraft og effekt? Det første handler om, hvordan relevansantagelser styrer læse- og fortolkningsprocessen:

"[D]et fortolkningsarbejde, der investeres i læseprocessen, når det gælder fiktion, [kræver,] at relevans opleves kontinuerligt. Der er grænser for enhvers tolerance over for udskudt tilfredsstillelse, og ingen endelig løsning vil med sandsynlighed alene kunne retfærdiggøre den indsats, det kræver at læse Prousts Recherche, eller [Tolstojs] Krig og fred, eller [Richardsons] Clarissa. Fiktionens narrative kraft afhænger af antagelser, der bliver opretholdt, beriget, modificeret, revurderet eller vendt på hovedet i læseprocessen: Selv i fiktion er narrativ udvikling kun mulig på basis af en etableret fornemmelse af relevans." (3I; 2013: 25)

Så det, der foregår, er - på læserens side - en relevansstyret fortolkningsproces, et spørgsmål om kontekstuelle antagelser og slutninger, sådan som Walsh udvikler det, idet han kritiserer, supplerer og udvikler Sperber og Wilsons perspektiver:

"Relevant information bliver i fiktion leveret af antagelser, der har kapacitet til at informere en kognitiv omgivelse, der omfatter selve antagelsen om fiktionalitet, så vel som et sæt af generelle antagelser, som samlet kunne kaldes "narrativ forståelse" (den ville omfatte logiske, evaluerende og affektive delsæt), og mere specifikke antagelser vedrørende for eksempel generiske forklaringer af en given tekst og dens indholds særegenheder. I denne kognitive omgivelse kan de kontekstuelle effekter, som udgør relevansen, være produceret af nye antagelser, der informerer den narrative forståelses projekt $i$ almindelighed (og andre slags forståelser, som dette kan gøre nemmere), eller ved antagelser, der muliggør yderligere slutninger fra de narrative enkeltheder, som selv vil bidrage til en vedvarende, kumulativ oplevelse af relevans (sådanne kumulative effekter vil være analoge med dem, som Sperber og Wilson - i deres diskussion af hvordan indtryk kan kommunikeres - kalder 'poetiske effekter')." (3I; 20I3: 25)

Ret beset (eller groft sagt) kunne dette måske (bortset fra antagelsen om fiktionalitet) i det store og hele vel nok også være en beskrivelse af "hvad der foregår" i læsningen af enhver fortælling, og ikke kun af fiktionsfortællingen. Men pointen er bare, at det netop er den kontekstuelle antagelse om fiktionalitet, der gør det relevant (og måske først og fremmest relevans-maksimerende) at drage den slutning, at fortællingen ikke refererer til eksisterende personer og ting. Derfor er det også sådan, at vi ved læsning af fiktionsfortællinger som regel ikke forsøger "at løse fiktive ytringers reference, for vi ved på forhånd, at i fraværet af ethvert bevis på det modsatte, vil deres bogstavelige sandhedsværdi være af for lille relevans til at være en bestemmelse værd" (32; 2013: 26). 
En anden pointe peger i samme retning: Hvis en fiktional fortælling kontinuerligt skal kunne opleves som relevant, kræver det i det mindste, at fortællingen på en eller anden måde opleves som kohærent. Men kohærens er selv betinget af et særligt sæt antagelser. For eksempel: Hvor "en læser af Processen finde[r] det relevant at konstruere nogle af de subtile hypoteser om psykologisk motivation, der er påkrævet for at forstå K.s adfærd”, hviler den narrative kohærens, der sørger for, at kumulative effekter kædes sammen, på "mere manifeste antagelser af en art, der er forbundet med den velkendte idé om, hvad der 'er sandt i fiktionen'. Sådanne antagelser har status af information uafhængig af ytringens bogstavelige sandhedsværdi, for deres validitet, det, at de er 'om noget', er en kontekstuel og ikke en referentiel validitet"19 (32; 2013: 26, min kursiv).

Et algebraisk eksempel tjener som illustration af den meningsfulde mulighed, at koreferencer (hvor flere forskellige udtryk (eller det samme udtryk flere gange) kan referere til den samme "ting" uden at påstå eksistensen af det, der refereres til. Når fortællingers bogstavelige sandhedsværdi har for lille relevans til at være en bestemmelse værd, er dét ikke noget, der kompromitterer fiktionernes narrative kohærens, for

"en vellykket referenceløsning er ikke nødvendig for, at koreferencer kan finde sted (tænk på algebra: Vi behøver ikke kende værdien af $\mathrm{x}$ for at vide, at $\mathrm{i} \mathrm{x}^{2}=2 \mathrm{xy}$ refererer hver forekomst af $x$ til den samme værdi, som også er to gange værdien af y).” (32; 2013: 26)

Skulle Walshs jongleren med termen "reference" her virke forvirrende, løses det ved termen "referenceløsning": I fiktioner er der ikke behov for referenceløsninger - forudsat, at man fastholder den pragmatiske tilgang og ikke behandler den fiktionale tekst som et semantisk spørgsmål:

"Den kommunikative effektivitet af mangfoldige referencer til fiktionale karakterer, steder og begivenheder er et pragmatisk spørgsmål, ikke et semantisk. Når en fiktional fortælling udfolder sig, bliver yderligere antagelser manifeste, ikke fordi tidligere antagelser har projiceret en fiktional verden, som den fiktionale sandhed af nye antagelser kan etableres i, men fordi den opnåede relevans af tidligere antagelser selv bliver en kontekstuel basis for at maksimere relevansen af efterfølgende, relaterede antagelser." (32; 2013: 26)

I9 At fiktion er "om noget", er muligvis en hentydning til den filosofiske diskussion om reference-begrebet og det urgamle problem i filosofihistorien, som jeg nævnte ovenfor i afsnittet om den antimimetiske position. (Crittenden bruger netop udtrykket at være "om noget", skønt ganske vist som et forsvar for brugen af ordet reference, når det peger på ikke-eksisterende forhold.) 
Jeg finder det sandsynligt, at det er problemet med at forklare, at koreferencer ikke kan placeres på linje med almindelige referencer, der har ført til, at eksplikationen af fiktionens ikke-reference har været så længe om at manifestere sig i teksten. I denne sammenhæng kunne man måske også placere den kendsgerning (som Walsh ganske vist ikke diskuterer i denne tekst, men som er en hovedpointe i Crittenden), at vi jo gerne refererer til fiktive personer og begivenheder, når vi taler eller skriver om fiktionsfortællinger. Sådanne referencer, antager jeg, refererer ikke til en fiktiv verden; de er koreferencer, en udvidelse af feltet for de koreferencer, som allerede foreligger $i$ den narrative fiktion.

Skønt disse smukke tekniske tydeliggørelser af muligheden for og relevansen af at opfatte fiktionalitet som ikke-referentiel kommunikation præsenterer en spændende og måske lidt besværlig rejse gennem et landskab, der er ukendt for mange, og skønt de generelt, men dog udførligt, præsenterer en idé om, ”hvad der foregår i fiktionen", mangler der måske endnu en mere specifik redegørelse for, hvad fortællinger gør (eller får os til at gøre) - altså "fiktionalitetens kraft og effekt i vor oplevelse af fiktion”. For Walsh handler dét måske om den særlige form for "viden”, den kommunikerer. Denne viden er "ikke primært en specifik viden om det, der er (eller var), men om, hvordan menneskelige forhold arter sig, eller mere præcist: om hvordan man kan finde mening i dem - logisk, evaluativt, emotionelt”. Men skønt velformuleret og på sin vis rammende, er en formulering som denne ikke opsigtsvækkende, den skyggebokser kun med (eller måske ligefrem "opdaterer") Aristoteles' formulering af forskellen mellem det faktiske eller historiske og det mulige. Og dog, over for narratologiens formale interesser er den en udfordring, fordi den taler om, hvad der traditionelt (og banalt) betegnes som fortællingens indhold. Men det er et "indhold", som ikke er selvstændiggjort og som ikke kan behandles uafhængig af fortællingens form, dens retorik, og altså også et indhold, der ikke kan henlægges til en fiktional verden. Så Walsh tilføjer (med et terminologisk lån fra Kierkegaard), at det her desuden drejer sig om en viden om, "hvordan sådanne spørgsmål kan bringes ind $i$ imaginationens sfare og $i$ den forstand blive forstået" (36; 20I3: 19, min kursiv). Imaginationens sfære er ikke en fiktional verden, ikke en ontologisk selvstændig størrelse, men måske snarere noget i retning af et sted, hvor vi kan "træne" for eksempel vor narrative forståelse. ${ }^{20}$

Men det afgørende fremstød mod fiktionens kommunikative hjerte sker måske alligevel først med en tætpakket bemærkning om, at en pragmatisk teori om fiktionalitet ikke begrænser fiktionens værdi til vidensforbedring, "selv ikke i den videste betydning, som jeg har antydet; [for en pragmatisk tilgang] hævder, at fiktioner tilbyder direkte kommunikerede gevinster, der stilles $i$ forgrunden ved selve den kontekstuelle antagelse om fiktion” (37; 2013: 30, min kursiv).

20 Jf. Walshs analogi i The Rhetoric of Fictionality: 50): "Fiktion, foreslår jeg, er forskellig fra ikke-fiktion på samme måde, som opøvelsen [the exercise] af vor narrative forståelse er forskellig fra dens anvendelse." 
De direkte [og altså ikke fingeret] kommunikerede (videns- og forståelses)gevinster "stilles i forgrunden": Formuleringen er et lån fra de tjekkiske formalister. Direkte kommunikation og forgrundstilling, det er faktisk også en præcis måde at beskrive, hvad det er, der karakteriserer den fortalbarhed, der kendetegner Pratts narrative display-tekster, tekster, der bevidner eller giver anledning til en særlig verbal "oplevelses-præsenterende og oplevelses-delagtiggørende aktivitet". Dette er, vil jeg antage, et væsentligt aspekt af "fiktionalitetens kraft og effekt i vor oplevelse og forståelse af fiktion”. ${ }^{21}$

Til sidst i Walshs tekst bliver en fiktionsfortællings kraft og dens effekt på læseren demonstreret $i$ et afsnit, som læser et stykke Kafka, og hvor Walsh indtager en position "uden for" fiktionen, idet han placerer sig bag en generaliseret læsers stol og kigger hende over skulderen (og samtidig optræeder som retorisk avanceret litteraturkritiker). Afsnittet fortjener at blive citeret i sin helhed:

"Indre fokalisering tilhører den klasse af ytringer, som Sperber og Wilson [1995] kalder "ekkoagtige" [...]. De får relevans, ikke alene gennem at levere information om andre personers tanker [...], men også ved at indtage en holdning til dem (I995: 238). Men hvilken holdning? Indre fokaliseringer omfatter mange afskygninger af ironi og sympati, og under forskellige fortolkninger kan denne særlige ekkolignende ytring tillade, at der sluttes til så vel den ene som den anden af de følgende antagelser:

(7) Josef K. var offer for en uretfærdighed.

(8) Josef K. var uvidende om den lov, under hvilken han blev arresteret.

Og selvfølgelig bliver yderligere antagelser manifeste i lys af læserens vurdering af disse to: at K. var blevet bagtalt, eller var et paranoidt offer (7), eller at han var blevet uretfærdigt anmeldt, eller var en paranoid og uvidende lovbryder (8). I en eller anden grad vil den dømmende natur af disse slutninger medføre affektive investeringer, der strækker sig fra dømmende distance til sympatisk engagement, og som tager form efter læserens emotionelle og ideologiske prædispositioner, hvad gælder forholdet mellem individ, selv eller subjekt og loven, med alt hvad det indebærer af konnotationer. Givet, at sagens tvetydighed forhindrer en klar præference for bare en af de tilgængelige konkurrerende antagelser, vil den affektive investering ( $\mathrm{i}$ en hvilken som helst ikke-reduktiv fortolkning) blive kompleks. Dette er selvfølgelig fundamentalt for effekten af den fortælling, der lige er begyndt, ikke mindst fordi Kafkas egen holdning til K.s penible situation er kompleks. I en vidunderlig passage nogle sider senere lader Kafka ham 'forsøge at se det ud

2I Denne artikels omfang har desværre medført, at jeg her må afstå fra at diskutere et par af Walshs antydninger om visse forbehold over for Pratts idé om narrative display-tekster. (Se f. eks. kritikken af Ryans forståelse af fortælbarhed (2007: 20; 2013: 13).) 
fra [hans egen] synsvinkel'. Der er en fin ligevægt mellem dømmende distance og imaginært engagement her: Læserens usikkerhed over for, hvordan den indre fokaliserings evalueringer skal opfattes, producerer en distancerende effekt, men samtidig producerer ligheden mellem læserusikkerhed og K.s egen ængstelighed ved tanken om at stå foran loven en investering, der får kvalitet af et affektivt engagement." (Walsh Rhetoric 35; 2013: I8)

Her har vi nok et stjerneeksempel på, hvad en fiktional narrativ diskurs kan gøre: Idet den tiltrækker sig vor fortolkende opmærksomhed og (som her) praktisk talt pånøder os kvikke læsere en række inkompatible antagelser, der uundgåeligt producerer usikkerhed hos os, men samtidig også tilbyder os en bevægelig position mellem distance og (affektivt) engagement, ${ }^{22}$ kommunikerer den med os (for så vidt som vi er i stand til at læse "ikke-reduktivt");23 den inviterer os til (med Pratts ord) at "tænke over det, evaluere det", "tage del i det", "fortolke det" (med hvad det implicerer af antagelser og slutninger) og "respondere på det".

\section{Fiktionalitetens retorik og narratologien}

Hvordan placerer Walshs syn på fiktionalitetens retorik sig i forhold til narratologiens ikke-pragmatiske traditioner, hvis generelle begreb om narrativitet fuldstændigt skubber spørgsmålet om fiktionalitet i baggrunden? På to måder: For det første som en generel markering af kritisk distance til narratologisk begrebslighed, for så vidt som den ikke medreflekterer fiktionalitet som en kommunikativ dimension i alle narrative medier. Til tider konkretiseres denne generelle distance i en kritik af enkelte begreber. Det gælder i denne tekst først og fremmest begrebet story, for så vidt som en fortællings story antages at eksistere uafhængigt af den tekst, i hvilken vi læser om den, i stedet for at blive set som et (relevansstyret) resultat af læsninger eller fortolkninger af teksten. Det gælder også kritikken af det traditionelle fortællerbegreb, som mange narratologer endnu betragter som ufravigeligt (jf. kapitel 4 i Rhetoric). Men i det store og hele er Walshs mange positionskritikker ikke rettet mod narratologien, men derimod mod andre fiktionsteorier (som Ryans og Pavels), og ikke mindst mod dele af den sproghandlingsteori, som han her selv arbejder i forlængelse af (først og fremmest Searle, som vi har set). På den anden side drejer

22 Drejer det sig her mon om psykologiserende antagelser om "ikke-reduktive" læseres adfærd? Skønt det er et spørgsmål, som der sikkert kan føres gode argumenter for at svare bekræftende på, finder jeg det mere påfaldende, at Walsh her under hånden genbruger begreber fra den formalistiske tradition. Vi har allerede set det med begrebet om at stille i forgrunden (eng. foregrounding), og vi ser det nu med iagttagelsen af ligheden mellem K.s og læserens ængstelighed: Roman Jakobsons metaforiske dimension.

23 Hvis der i dette afsnit måske findes en antydning af (selv)ironi, skyldes det, at jeg her ikke har mulighed for at gå nærmere ind på, hvad der hos Walsh ser ud til at være en skygge af en publikumsteori, der ligesom Rabinowitz (1977) skelner mellem typer af naive læsere (som lader sig forføre til at "tro" på fiktionen), og så mere eller mindre litterært erfarne eller "indforståede" læsere: det narrative, det autoriale og forfatterens ideale publikum. Spørgsmålet om kommunikation er her selvfølgelig også et spørgsmål om de kommunikerendes forudsætninger $i$ form af viden og erfaring (ikke mindst med litteratur). 
det sig også om en (måske provisorisk) tilslutning til narratologisk begrebslighed. Vi ser den navnlig i den passus, der bruger et Kafka-citat for at afvise talehandlingsteoriens standardforklaring på ”litterær diskurs”:

"Den fingerede talehandlings ramme redegør ikke for fiktionalitet, for fiktionalitetens retorik er ofte selve narrationen iboende. Den første sætning i mit citat fra Processen, for eksempel, yder modstand mod at blive restitueret som fingeret ikke-fiktional sproghandling, både hvad gælder dens indhold (adgang til en andens tanker) og dens form (den indre fokaliserings dobbelte tidslighed, manifesteret i det ellers anomale 'nu')." (Walsh The Rhetoric of Fictionality 20; 20I3: I6; min kursiv)

Kafkas sætninger "yder modstand mod" at blive forklaret som fingerede talehandlinger, og denne modstand skyldes, at Kafka bruger narrative teknikker som indre fokalisering og dækket direkte tale - teknikker der producerer tekstuelle forhold, som tiltrækker sig en særlig fortolkende opmærksomhed. Det er disse teknikker velbeskrevne i narratologiens formale analyser - der her bliver opfattet som retoriske ressourcer ${ }^{24}$. De er tillige de retoriske ressourcer, som Walsh nævner flest gange i dette kapitel. Således forstår vi måske bedre, hvad han sigter til, når han siger, at en pragmatisk tilgang ikke står, og ikke bør stå "i modsætning til, hvad vi nu for tiden gør som læsere eller kritikere” (37; 20I3: 3I).

Men selvom fiktionalitetens retorik ofte er narrationen iboende, så er "en retorisk definition af fiktionalitet pragmatisk derved, at dens kriterier i sidste instans ikke er inhærente i fortællingen selv, men [...] kontekstuelle" (Walsh Rhetoric 38). Og kontekster har det som bekendt med at ændre sig med tiden - med nye fortællinger, nye historier, nye medier, ja, opkomsten af fx "fiktiobiografiske" tekster er måske allerede ved at ændre dem en smule?25

En teori om fiktion har længe manglet i traditionelle narratologiske sammenhænge; den har ikke engang været efterspurgt. "Hvad skulle man dog bruge en sådan teori til? Er det ikke tilstrækkeligt at vide, at fiktions- og ikke-fiktionsfortællinger er to forskellige ting, eller genrer, om man vil?” Jeg tror, der blandt mange narratologer (og mange lingvister) stadigvæk er en tilbøjelighed til at betragte diskussioner om fiktion som en art filosofisk tidsfordriv uden seriøs betydning for det, der er deres professionelle virksomhed og interesser. "Se bare på filosofferne, siden Aristoteles har de i over 2000 år ført endeløse og sikkert interessante diskussioner uden at blive enige om noget som helst.” Men pointen er ikke at nå frem til nogen som helst form for filosofisk enighed. Fra tid til anden sker det, at selv en filosof gør oprør mod filosofien som sådan. Wittgenstein var en sådan filosof, og hans oprør blev inspiration for en ny dimension i lingvistikken. Denne har sine begrænsninger,

24 Her finder vi sandsynligvis forklaringen på dette "genkendelige retoriske sæt", som Walsh nævner indledningsvist (jf. note 6 ovenfor).

25 Se Jacobsen. 
selvfølgelig, sine komiske øjeblikke og ideologiske blindpunkter, ${ }^{26}$ men den har ikke desto mindre leveret spændende resultater og åbnet nye veje. Noget af det mest interessante ved Walshs projekt er for mig at se, at det tager vejen om denne relativt nye lingvistiske tradition, som ikke har produceret noget fiktionalitetsbegreb, for at give narratologien et begreb om noget, som den traditionelt ikke har vist synderlig interesse for. Det bryder ind i både filosofiske og lingvistiske diskurser og foreslår med uhørt radikal konsekvens en teori, som, skønt den ikke uden videre leverer en alternativ narratologi, dog åbner traditionel narratologi for pragmatiske dimensioner, som har været og stadigvæk er den fremmed, og det demonstrerer samtidig (hvad mange fiktionsteoretikere sikkert har drømt om), ikke alene hvad en fiktions- og fiktionalitetsteori kan bruges til, men også hvor nødvendig den kan vise sig at blive (og efter min mening allerede er). ${ }^{27}$

\section{LITTERATURLISTE}

Allan, Keith \& Kasia M. Jaszczolt (red.) The Cambridge Handbook of Pragmatics. Cambridge: Cambridge University Press, 2012.

Austin, J.L. How to do Things with Words. Oxford: Clarendon Press, 1962.

Cavell, Stanley. Must we mean what we say? A book of essays. London og New York: Cambridge University Press, 1967.

Cavell, Stanley. The Claim of Reason. Wittgenstein, Skepticism, Morality and Tragedy. Oxford: Oxford University Press, 1979.

Cohn, Dorrit. The Distinction of Fiction. Baltimore og London: Johns Hopkins University Press, 1999.

Crittenden, Charles. Unreality. The Metaphysics of Fictional Objects. Ithaca og London: Cornell University Press, I99I.

Derrida, Jacques. "Structure, Sign and Play in the Discourse of the Human Sciences", i: The Languages of Criticism and the Sciences of Man: The Structuralist Controversy, red. Richard Macksey og Eugenio Donato. Baltimore: Johns Hopkins University Press, 1966.

Duprat, Anne. "Stultitia loquitor: Fiction and Folly in Early Modern Literature". Comparative Critical Studies, 5, 2-3: I4I-I5I, 2008.

Vraisemblances. Poétiques et théories dela fiction, du Cinquecento à Jean Chapelain. Paris: Champion, 2008. Fludernik, Monika. Towards a 'Natural' Narratology. London and New York: Routledge, 1996.

Genette, Gérard. "Discours du récit. Essai de méthode”, in Figures III. Paris: Seuil, 1972.

Genette, Gérard. Narrative Discourse. An Essay in Method. New York: Cornell University Press, 1980.

Genette, Gérard. "The Pragmatic Status of Narrative Fiction". Style 24.I: 59-72, 1990.

26 For en dybtgående filosofisk kritik af Austins "teknificering" af Wittgensteins sprogteori, se den store Wittgensteinkender Stanley Cavell.

27 Jeg tænker her selvfølgelig ikke mindst på Walshs (i bogen uudfoldede, men suggestive) invitation til radikalt at udvide fiktionalitetsteorien til ikke-institutionaliserede medier og sprogbrugssituationer, og i særdeleshed situationer, der kompliceres af, at teksterne blander fiktion og ikke-fiktion. Jf. Nielsen 20II. (I foreliggende artikel har der desværre ikke været plads til yderligere kommentarer om denne udvidede fiktionalitetsteori.) 
Gjerlevsen, Simona Zetterberg. "En seriøs sprogteoretisk fiktionalitetsdefinition". Kひ K, i foreliggende nummer.

Grice, H.P. Studies in the Ways of Words. Cambridge, MA: Harvard University Press, 1989. Hamburger, Käte. Die Logik der Dichtung. Stuttgart: Ernst Klett, 1957.

Hamburger, Käte. The Logic of Literature. Bloomington: Indiana University Press, 1973.

Hamburger, Käte. Logique des genres littéraires. Paris: Seuil, 1986.

Jacobsen, Louise Brix. "Fiktiobiografisme. Perception og fiktionalisering". Spring 31/32, $201 \mathrm{I}$.

Kafka, Franz. The Trial. Harmondsworth: Penguin, 1994.

Labov, William. The Social Stratification of English in New York City. Washington, D.C.: Center for Applied Linguistics, 1966.

Labov, William. Language in the Inner City. University Park: University of Pennsylvania Press, 1972.

Lubbock, Percy. The Craft of Fiction [1921]. New York: Jonathan Cape and Harrison Smith, 1929.

Nielsen, Henrik Skov. Tertium datur - Om litteraturen eller det ikke-varende. u.st.: Forlaget Bindslev, 2003.

Nielsen, Henrik Skov. "Fiktion, fiktionalitet og unaturlige fortællinger". Spring 31/32, 201 .

Ohman, R. "Speech Acts and the Definition of Literature". Philosophy and Rhetoric 4: I-I9, I97I.

Pavel, Thomas G. Fictional Worlds. Cambridge. MA: Cambridge University Press, 1986.

Pratt, Mary Louise. Toward a Speech Act Theory of Literary Discourse. Bloomington: Indiana University Press, 1977.

Pratt, Mary Louise. "Ideology and Speech-Act Theory". Poetics Today, 7, I: 59-72, 1986.

Rabinowitz, Peter. "Truth in Fiction. A Reexamination of Audiences". Critical Inquiry 4,I, 1977.

Reitan, Rolf. "The Rhetoric of Fictionality. Introduktion til Richard Walsh". Spring 3I/32, $201 \mathrm{I}$.

Russell, Bertrand. "On denoting". Mind I4: 479-93. (Genoptrykt i Logic and Knowledge: Essays 19oI-1950. London: Allen and Unwin, 1956.)

Ryan, Marie-Laure. Possible Worlds, Artificial Intelligence and Narrative Theory. Bloomington: Indiana University Press, I99I.

Scholes, Robert \& Robert Kellog. The Nature of Narrative. Oxford: Oxford University Press, 1966.

Searle, John R. "The Logical Status of Fictional Discourse". New Literary History 6.2: 319-32, I975.

Sperber, Dan \& Deirdre Wilson. Relevance: Communication and Cognition, 2. udg. Oxford: Blackwell, 1995 .

Sperber, Dan \& Deirdre Wilson. Meaning and Relevance. Cambridge: Cambridge University Press, 2012. Walsh, Richard. Novel Arguments. Cambridge: Cambridge University Press, 1995.

Walsh, Richard. The Rhetoric of Fictionality. Narrative Theory and the Idea of Fiction. Columbus: The Ohio State University Press, 2007.

Walsh, Richard. "Den narrative fiktions pragmatik", dansk overs. af "The Pragmatics of Narrative Fictionality" (I. kap. af Walsh 2007), i foreliggende nummer af Kఓ $K$, 2013. 